\title{
SYMPOSIUM ON THE INANGAHUA EARTHQUAKE
}

\author{
W. J. H. Duckworth \\ J. P. Hollings \\ B. H. Falconer \\ H. C. Hitchcock
}

on Railways

Bridges

Buildings

Electrical Services*

\section{introduction}

A symposium on the Inangahua Earthquake of 24 May 1968 was held by the society on the afternoon of 12 February 1969. as a section of the 1969 Conference of the New Zealand Institution of Engineers, at the victoria University of Wellington.

Papers presented by the four speakers had appeared in the December 1968 issue of the Bulletin, Vol. 1 No. 2. At the symposium each paper was introduced by the speakers, and the available time was conserved to enable members of the audience to contribute to the discussion and for the speakers to reply. Much of the material presented included charts and colourslides which cannot be reproduced here. Mr G. F. Bridges, Chief Civil Engineex of the New zealand Railways, was the session chairman.

A verbal record was taken. The following material is a summary of the presentations, notes, discussion and replies, as prepared by the reporter. The symposium was held immediately in advance of the publication of the February 1969 issue of the Bulletin. vol. 2 No. 1. which is devoted to a preliminary report on the Inangahua Earthquake from an overall viewpoint with contributions by many authors.

* A set of Conference Seminar Papers, including the relevant papers by the four speakers in the symposium, appeared in Bulletin Vol 1 No. 2 December 1968. 
W.J.H. DUCKWORTH (Greymouth) said that in the Inangahua earthquake of 24 May 1968, about 60 miles of railway track were damaged, as were numerous buildings, bridges, and other structures. To restore the track, 42,000 cubic yards of ballast and sub-ballast were used, and 19,000 cubic yards of filling, and the total slip excavation was 30,000 cubic yards. The cost of the restoration was $\$ 371,000$. The railway lines were opened for reduced speed traffic on 17 June, and normal running resumed on 24 september. A total of 265 work trains and 20 earth-moving machines were used in the repair work, and the maximum number of staff on the site was 180, the food bill for half of that staff being $\$ 3,572$. In general, where the line was laid on firm flat ground, little foundation damage occurred, only the ballast section being disturbed and the track distorted, but where the track was laid in sidlings or cuttings, slips, rock falls, and rock slides occurred.

The question to be considered was how a facility could be constructed so that it would stand catastrophes of the Inangahua type. Not much could be done to forestall or withstand a slide of 2,000,000 to 3,000,000 yards of material, but better care could have prevented trees from growing near the edge of batters and eventually falling on to the track, and instability would not have been so widespread if greater attention had been given to the maintenance of cut-off drains, and if batter slabs had been flatter. The characteristic failure pattern of the fills was a downward movement of approximately 1 to $2 \mathrm{ft}$. to the lowest unconfined level. In a few cases, the settlement was of the order of $5 \mathrm{ft..}$ and there was also, in one or two cases, the common slip type of failure.

What lessons were to be learned from the earthquake? Ground type was important, and the firmer the underlying ground, the greater the resistance to settlement. The fill type was also important, and clays tended to be more unstable than shingle fills. The compaction of embankments was another important point, and the old side-tip and end-tip systems were less likely to stand up to earthquake forces than modern compaction techniques. Water content was of great significance, as was proved by the collapse of an embankment 70 miles away from the main damage, because it was heavily saturated, while embankments closer to the scene suffered far less damage. 
The main conclusion was that design standards and construction practices of the past were inadequate in the face of an earthquake of the magnitude of the Inangahua one, and it might even be felt that some current practices were suspect. The Inangahua earthquake had merely disturbed a small community, but the next one might hit a metropolitan area. As engineers, what could they do to minimise its effects?

J. P. HOLLINGS (Wellington) said he proposed to take the Buller Bridge for discussion, as being the most modern. It had been built in the late 1930s, and was therefore not too far removed from current bridge design practice. It was stronger laterally than longitudinally (flood versus traction and braking) and probably received the main shock longitudinally, and as a result the longitudinal response was the most noticeable. In a conventional analysis for design purposes, the pier (as illustrated) would be considered as fixed some distance below the river-bed surface, and a static coefficient would be applied to the superstructure. An elementary analysis would show that at the critical section at the base of the piers there was a load factor of at least 1.27 for the moments produced by those static loads, and the clearances provided at the sliding joints of \pm 1 inch covered the predicted elastic deflections under the code loads by a factor of 2.6. The movement at sliding joints was finally limited by holding down bolts with a shear capacity at each joint approximately equal to the weight of one span. which was equivalent to saring the structure was through tied for a static earthquake force equal to the span weight. Therefore the bridge was apparently of adequate strength, with adequate allowance for movement, and was adequately through tied. Notwithstanding those apparently adequate margins and notwithstanding that the earthquake intensity was really no larger than that of the design earthquake on which the code loads were based damaging movements occurred. At the critical section at the base of the piers there was evidence of several cycles of reversal of bending right up to the ultimate moment capacity of the pier in each direction; the sliding clearances were closed up to their full limits or beyond at every pier; and the holding-down bolts at the sliding joints were sheared or nearly so at every pier and were saved from complete failure only by other paths available for the axial deck forces.

If the code conventions were put to one side and the actual behaviour of the bridge examined, three major influences would be found to have been at work during the earthquake:- 
1. The ordinary inertia response of the deck and the upper part of the piers as conventionalised in the code (plastic hinges had formed at the base of each pier);

2. The inertial response of the alluvial soils overlying the rock (without some such action the slopes on the piers below river-bed level could not be explained);

3. The slumping of the abutment fills.

The proportions in which those three factors had influenced the performance of the bridge could not be quantitatively stated with confidence, although research was being done on the combined alluvial-ground and structural response.

Qualitatively, however, the evidence was that the bridge superstructure had begun oscillating with a natural period of about 0.4 seconds, and calculations of the damping available from the rail system, which was being aragged and thrust across the ground surface on each side of the bridge, suggested a damping factor of about 10 per cent. On the El Centro earthquake spectrum that would give a maximum acceleration response of about $0.8 \mathrm{~g}$. , and that effect alone would be sufficient to cause yield at the pier bases. However, that concept presupposed that the piers were rigidly fixed into the alluvial soil, and long before the superstructure response was reached the soils would be responding too. Work done on earth dams suggested that the natural period of the soils of the depth and type on that particular site would be in the range $\frac{1}{4}$ to $\frac{3}{4}$ seconds, which was close to that of the bridge structure. As a result, the combined effect of superstructure and foundation response would be that far from giving support to the piers the alluvial soil response would magnify, probably very substantially, the superstructure response.

With the deck of the bridge oscillating violently longitudinally with an amplitude of probably a foot or more. at each abutment the abutment structure could easily move towards the river as it was pulled at the top by the moving bridge deck; that would be followed by the slumping abutment fill, so that on the return motion the top of the abutment was thrust into the ground by the full kinetic energy of the moving superstructure and against the reaction of the full passive resistance of the abutment backfill. That concept would explain the jack-knifing which had occurred half-way down the south bank abutment and at pier 2 of the bridge, and also at both abutments of the Inangahua Bridge. That the battering ram effect of the deck had caused the abutment jack-knifing, rather than active earth pressure due to 
approach fill slumping or liquefaction, could be checked from the geometry of the failed abutment, where the ultimate moment at the plastic hinge could be calculated reliably and was consistent only with passive forces and not active ones in the fill.

A general understanding of the nature of the bridge's performance in an earthquake was of the greatest value to a practical designer, notwithstanding the lack of quantitative data available, because such an understanding could be used (instead of blindly following the codes) to achieve the earthquake performance the designer required from the bridge in a severe shaking. The prime aim of a railway bridge designer was to ensure that the bridge was capable of carrying traffic as soon as possible after the earthquake and to do that it was essential that the spans should remain on the piers. Experience in past earthquakes had shown that at the sliding joints provided in long bridges the details were vulnerable, so that the spans commonly cameapart and fell down, but it was now recognised that through tying of the spans at the sliding joints was essential to retain the bridge's integrity in a severe shaking. It was not easy to decide how strong such ties should be, because designers were often influenced by the approach set out in the code, and arbitrary figures were taken, such as an acceleration of $\mathrm{lg}$. applied to the mass of the deck. on the other hand, a rational upper limit to the tie force, based on an understanding of the bridge performance, could be obtained by examining the maximum shear force which could be fed into the deck by each pier. That shear force could not exceed the plastic hinge capacity of the pier base divided by the pier height (pinned top pier). Thus, if external restraints at the bridge ends were removed, the maximum value of the deck tensions could not exceed the shear force per pier top times half the total number of piers. For the Buller Bridge that gave a figure of $540 \mathrm{kips}$, which bore no relationship to the arbitrary assessments which were commonly adopted - such as lg. applied to the individual span mass, which would be only $185 \mathrm{kips}$ - further proof that through a study of the performance of real structures in a severe shaking bridge designers could obtain practical guidance for design which was of far greater value than the application of conventional design codes.

N. A. BANNATYNE (Wellington) congratulated Mr Duckworth on his published paper, and also on the award he had received in the New Year Honours for the part he had played in restoration work. That work had been done under difficulties, as he had been obliged to vacate his office in Greymouth as the result of earthquake damage and to exercise control from makeshift headquarters. The aftershakes had been particularly frightening and hazardous, and had been one reason for no night work being done on rail tracks. He asked whether, in the carrying out of the restoration work. some of the lessons for the future 
mentioned in the paper had been put into practice as a matter of expediency, and, in work of such a nature, how the balance between permanence and expediency could be held. Referring to damage to the limestone bluffs at Whitecliffs, he asked the author's view of the stability of the massive blocks which had been slightly displaced but had not fallen.

A. G. STIRRAT (Wellington) said that the record of measurements and observations in the paper by Mr Hollings and Mr Fraser were an invaluable contribution towards knowledge of the behaviour of bridges under seismic loading. For too long engineers had been prepared, if not content, to apply the arbitrary provisions of a code of practice without any real understanding of the behaviour of a bridge structure in its entirety. The multi simple span Buller Bridge, with its fixed and sliding joints, was typical of many built over the past 40 years and still being built, and the observations of the authors should be studied carefully. It had been made clear that a bridge could not be studied in isolation from its foundations and approaches, because much of the movement observed was a result of the behaviour of the foundation material under seismic loading - not only the material on which the structure was founded, but also that surrounding the foundations. It was obvious that knowledge of abutments which had approach fillings incorporated in them was far from complete.

Mr Stirrat asked Mr Hollings to comment further on the need for study of the composite action between foundation materials and structure, and ways and means by which this could be implemented. A major problem in the design of urban motorway structures was the very large retaining walls, upwards of $50 \mathrm{ft}$. in height, which had to be built, and he felt that the conventional methods available for the design of such retaining walls did not satisfy seismic conditions. The use of linkage bolts had been standard practice in his department for the past 12 years. In a structure like the Buller Bridge, where it would be assumed that each pier resisted seismic forces from one span, the linkage bolts would be designed to transfer the lateral force from one span to the next. The evidence in the paper seemed to indicate that a far better fail safe arrangement should be considered to ensure that spans did not drop off the piers.

\section{R. W. SMITH (Dannevirke) said that from an inspection of} photographs of damage to bridges and their approaches, a failure common to many appeared to be a marked subsidence of the approach fillings. It appeared that if those bridges had been built with friction slabs for earthquake resistance the slabs would have been broken off close to the bridge. Whether they would have served their protective function before being broken would be hard to say, but a repair job afterwards would be very difficult. 
He asked for Mr Hollings's comments on the desirability of using friction slabs in bridge designs.

J. B. WILSON (Wellington) said he had been a member of the Railway team at Inangahua during the earthquake restoration work. He considered that the department had been fortunate in not having a major problem with the old combined rail and road bridge over the Inangahua River at Landing. Had that bridge collapsed, both the time and cost of restoration of the railway line to Westport would have been much increased. He commended the work of Mr G. W. Butcher, consulting engineer, for his valuable potential service in standing by with a complete proposal for the emergency replacement of the Landing bridge had that proved necessary. The bridge was on mass concrete supports, and after the earthquake one of the end trusses had remained precariously perched on shattered mass concrete blocks. Trusses had been known to stand up without end support, but the Kowhai viaduct collapse some years ago had indicated that heavy blocks of concrete bolted on to the unsupported truss (as was also the case at Landing) did not help matters. In the event, underpinning had been successful.

Consequent on the earthquake, the Chief Civil Engineer of the Railways Department had directed improved preparedness for the possibility of such emergencies in the future, and new standard emergency railway bridging was being provided. A monetary grant had also been made by the Railways Department to Canterbury University in order to assist with research and development of improved seismic resistant designs for concrete construction, and already work of promise seemed to be emerging as a result.

G. L. EVANS (Christchurch) said that of 50 highway bridges within 25 miles of Inangahua, 30 had shown measurable displacements and 20 had been damaged in some way, conditions such as the following being quite general:

1. Settlement of abutment fills and some sideways spreading which could be attributed to recompaction under seismic oscillation.

2. Displacement of abutments relatively towards each other with wingwalls cracking and moving outwards. The shearing of holding down bolts, cracking of $4 \mathrm{ft}$. diameter reinforced concrete cylinders and mass concrete abutments $7 \mathrm{ft}$. thick indicated that forces on the abutments were very high. 
3. The closing of joints between spans with relative longitudinal movement between superstructure and substructure. That had not damaged superstructures much, but only fixings on piers and abutments. At piers supporting simple steel spans, holding down bolts were bent towards each other, and on a continuous steel span the movement was only in one direction.

4. The forming of plastic hinges at top and bottom of piers, indicating a longitudinal rocking motion. At monolithic pier beam connections a crack occurred at the underside of beams. On simple bolted steel beams rocking at the top was not so obvious. but mortar pads under beam seats crushed. At the bottom the piers cracked either just above pile caps or in the concrete piles just below the cap.

5. With heavy massive piers, shearing and displacement occurred at ground level in the foundation cylinders. This shearing appeared to have been caused by a ground movement that was not occurring in the superstructure at the same time.

The seismic motions imposed on the structures had varied in amplitude and direction, but displacement evidence suggested that only a few major impulse movements had caused damage. A simplified seismic mechanism could be suggested, which appeared to account for most of the observed damage to railway bridges. A translational impulse movement hitting one end of a bridge first could create high abutment pressure while causing a longitudinal movement of the superstructure with consequent damage at both ends of the bridge. The translational movement could be faster through the superstructure than through the ground, causing the piers to rock.

Seismic design of bridges should provide for:

1. high earth pressure and displacement at abutments;

2. differential movement between superstructure and ground causing piers to rock.

The basic problem was the determination of some criteria for the design pressure and allowable displacement.

From the investigation of railway bridge damage, was there any indication of the impact force on the abutments, and the sequence or mechanism causing the damage? 
Mr Evans asked Mr Duckworth whether there had been any eye-witness report of what the earthquake looked like.

Mr DUCKWORTH, replying to Mr Bannatyne's query about expediency and permanency, said that in his view the choice made had been a "satisficing" solution. On the question of the stability of the limestone bluffs at Whitecliffs, he said that although there were enormous cracks, there had been no slips there since the earthquake and he assumed the bluffs would stay as they were until there was another magnitude 7 earthquake.

Mr HOLLINGS, on the question of foundation and superstructure interaction, said that universities were working on an analytical solution to the problem but the first point to be resolved was the elastic response of the soil. The problem had then to be taken further to incorporate the concept of permanent or plastic deformation in the soil, and he did not know whether an analytical solution to that was even possible. As to how to deal with the problem currently, he referred to page 93 of Vol. 1. No. 2 of the Bulletin of the New zealand Society for Earthquake Engineering, where Mr Wilson set out three seismic resisting priorities for a bridge subjected to a major shock: that (a) loss of life was avoided; (b) spans remained on piers in order to facilitate resumption of traffic; (c) damage to the bridge was an economic minimum. He felt that until the foundation superstructure interaction problem was solved analytically - if it ever was bridge designers could only work intuitively towards those three aims, with the assistance of whatever information they could glean from the performance of actual bridges in earthquakes.

On the subject of friction slabs, he said it was one detail which had to be considered in the whole design process. He could only comment that railway bridges, with hundreds of yards of track on either side, had still been damaged. Concerning the impact force on the abutments. some idea of that could be obtained from the actual structural geometry of the abutments as shown in the chart. The moment of the plastic hinge at the crack could be calculated quite reliably, and the impact forces on the abutment could also be obtained reliably.

\section{Afternoon tea adjournment}

B. H. FALCONER (Auckland) quoted the conclusion of Mr W. R. Stephenson's paper on Engineering Seismology in the preliminary report of the Department of Scientific and Industrial Research, Bulletin 19j: "Because there were no major engineering works or 
multi-storey buildings in the area, the main lessons for engineering seismology were indirect. The low casualties and relatively low damage may lead to the severity of this earthquake being overlooked." That conclusion was also relevant for the lessons to be learned for general building design and construction - because of the remoteness, the topography, the light population, and the particular form and age of the timber dwellings. Perhaps the prime lesson for the future was that designated people should be prepared to act promptly to observe and record relevant data, by planning to do so in advance of any earthquake. Any such plan would need to be elastic to be effective.

of great value to the symposium would have been a collective report from a team covering three aspects:

1. a systematic record, immediately commenced, of the nature and extent of damage to buildings, structures, contents, and services, compiled by persons with adequate time because they had no other responsibility;

2. recordings on strong motion instruments of the after shocks, in that particular case up to magnitude 5.9, by an array of accelerometers and seismoscopes promptly set down in the epicentral area by helicopter and situated on the representative grounds of rock, hard sediments, and soft soils;

3. a review of 1 and 2 inter-related with the vulnerability of natural and man-built structures, and with the incidence of damages and losses.

The question would arise in the minds of some listeners whether New Zealand, a small remote country, hard pressed financially, could afford such luxury of scientific and engineering study, but, in view of the amount of property at risk in the areas of population and industry concentration, he would pose the reverse question - whether they could afford not to make such a detailed study the next time a comparable opportunity came.

The Inangahua earthquake had caused severe damage to buildings at the township comprising Inangahua Junction and Inangahua camp, and to farmlands within a radius of 5 to 8 miles. Within that area, secondary effects of the earthquake had included conspicuous cracks in the ground, small craters from sand ejected to the surface of pasture on low lying river terraces, a variety of landslides. collapses of domestic chimneys, partial collapses of tile roofs of dwellings, and timber-frame dwellings moved on or moved off their foundations. That indicated 
in the Modified Mercalli scale, 1956 version, a felt intensity of MM.VIII to MM.X in the epicentral region.

Within the area of the MM.X isoseismal were the settlements of the camp and junction, comprising a township of some 50 houses, a school, post office, two churches, hotel, motel, petrol station, tea room and shop. Most of the dwellings in the township were state owned. In the farmland of the rest of the area of prime damage were some 30 farm dwellings with ancillary stores, milking sheds, and implement sheds.

All dwellings in the area were timber framed. External walls were of weather board, except for two Electricity Department houses with brick veneer walls. Roofs were of galvanised iron sheeting, except for eight state owned houses with tile roofs. Relatively few buildings had sound foundations such as timber base plates of walls bolted to a continuous concrete foundation strip around the perimeter. The farm dwellings and most nonGovernment built dwellings generally were supported by an array of free standing timber piles. Many such structures moved sideways as the timber piles folded over from vertical to horizontal. Differential movements occurred in most cases.

Severe damage occurred to unreinforced brick or concrete block chimneys, either because of inherent weakness of the material or because the chimney bases were brittle and provided greater rigidity for lateral movements than did the foundations. Many external chimneys collapsed completely to rubble. Several internal chimneys with poorly bonded bricks, in addition to collapsing above the roof line, spread laterally within the confined space, bulging the building walls locally. There were no buildings with masonry bearing walls other than two minor farm sheds with unreinforced concrete block perimeter walls in which the mortar was effectively unbonded to the blocks. The block walls collapsed.

As stated earlier, the lessons to be learnt were mainly indirect. It was a valuable engineering experience to observe that damage to buildings could occur by three means:

1. by distortion of the ground, with consequent distortion of the building structure,

(a) by subsidence or compaction of ground;

(b) by rock falls, landslides, or lurching of soil;

2. by oscillation of the building structure due to ground vibrations, causing damage through overstress,

(a) from direct inertial forces; 
(b) by induced forces from the differential movements of component members or the movements at joints or junctions;

3. by combinations of 1 and 2 .

Thus it was necessary for a designer to consider interactions of ground and structure. Designers should consider not only an equivalent static design force based upon a code co-efficient or even an analysis of dynamic response, but the possible or probable mechanism of failure of the structure. They should consider also the extent of distress which could be accepted. any requirements for interim serviceability prior to repair. the feasibility of procedure of repair, and, ideally, the costbenefit of precautions.

H. C. HITCHCOCK (Wellington) said his paper was a brief summary of the effect of the earthquake on electricity services provided in the area by the Buller, Grey, and Waimea Power Boards and the New Zealand Electricity Department. The map with the paper showed those areas, and also the estimated location of the epicentre of the main shock and its distance from the principal installations.

The main shock interrupted electricity supply over most of the northern end of the South Island, and in some places also in the North Island, but where that was due to false operation of Bucholz relays power was restored in a few minutes. It was over three hours before temporary repairs and bypassing arrangements at Inangahua made power available at Waimangaroa and Westport, and it was still later before supply could be provided in Inangahua itself.

N.Z.E.D. radio and telephone facilities initially provided the only links with the worst affected areas and were the means of conveying the evacuation order when the flood threatened when the upper Buller Gorge was blocked by slip. N.Z.E.D. staff and vehicles also carried out the evacuation of nearly 50 of the women and children.

The high voltage equipment involved in the area was mostly designed for only $66 \mathrm{kV}$ or in some cases $110 \mathrm{kV}$, so the detailed reports of damage were similar to those made after the Napier earthquake in 1931.

The effects of the earthquake could be summarised thus: contrary to popular opinion, the design of transmission line towers and terminal gantries was dominated by wind loading, and the earthquake loading of such structures was almost insignificant. There was a risk of failure with transmission lines, as had been 
166

graphically demonstrated in the picture provided by the

Geological Survey. The worst damage to the towers was at a point on top of a ridge of poorly consolidated alluvial material near Dee Creek, 2 miles north of Inangahua. The upper levels of the ridge were shaken in an almost incredible manner, and the whole top of the ridge was almost disintegrated. The towers on the top of the ridge had cracks running through their foundations. They had been so disturbed that in one case the grillage footing of the tower had been twisted to such an extent that one of the angle legs was fractured, but those towers still stood up and carried power until arrangements were made for a deviation some weeks afterwards.

Inangahua was some 9 miles from the epicentre, but was in the zone of maximum ground damage and shaking. The greatest damage there was to the electrical equipment in the small control building, where the station battery and the control and communications panels were overturned because of their relatively light fastening. In the outdoor switching station the steel structure was undamaged, because it had been designed for a wind loading and had very large foundations of very great strength. The bulk oil type circuit breakers set flat on their concrete foundations were quite undamaged. Because of relative movement between the steel tower and adjacent structures, the jumper connections snapped off certain of the insulators and these swung down on the ends of the jumpers and in one case broke the neutral bushing transformer and in another case the support insulator. The small staff of the substation were able to carry out sufficient repair work to bypass the inoperative circuit breakers and allow power to be resumed.

Concerning the relative behaviour of buildings under strain, of the eight departmental houses, the two of brick veneer suffered the most damage, but the wooden houses were also shaken violently. with furniture being overturned and material thrown out of cupboards. The depot building, which had very light bracing, was shaken very violently, with door hinges being torn from the door posts. On the other hand, the small control building did not suffer any kind of damage, and there were not even any cracks visible in the paint.

At Reefton, 26 miles from the epicentre, the shaking was not nearly so violent, but some 16 ton transformers which were clamped to rails had their clamps dragged along the rails by about $1 \frac{1}{2}$ in, in spite of being fixed by $\frac{3}{4} "$ bolts. The nearby houses, which were of wood, on partial foundations, were not actually damaged but they were violently shaken and articles were thrown off shelves and out of cupboards. Only a few feet away from the transformers, a reinforced concrete block depot and workshop, built on a concrete slab at ground level, suffered only hardly 
discernible cracks and none of the tools and material on benches and shelves had been displaced.

The Murchison substation, only $1 \frac{1}{2}$ miles from the Post Office where $.3 \mathrm{~g}$ maximum ground acceleration was recorded, suffered no damage whatever. Retail power distribution in the area was the responsibility of power boards, and they reported that many service connections to houses were damaged, there was some clashing of overhead wires, and some poles leaned over or were carried out of alignment, or in some cases sank deeper by as much as $3 \mathrm{ft.}$, as a result of the slumping of the roads and embankments. Two small boards with hydro generating plant reported some damage to civil engineering works, and the two boards supplying the coal mining areas reported a very heavy increase in electricity demand of 15 per cent to 20 per cent when consumers turned to electric heating because of broken chimneys.

In summary, Mr Hitchcock said that anti-earthquake design of transmission lines consisted primarily of selecting tower sites least likely to be affected by earthquakes. The advice of a geologist had been sought in selecting routes for deviations made necessary by ground failures in the Buller Gorge. The damage to battery and control panels emphasised that earthquake design should attend to minor detail with great care if major provisions were not to be nullified. The damage caused by tight jumpers repeated the experience at Napier. The earthquake release clamps were devised at that time, but they proved unsatisfactory because they gave trouble in storm conditions and became increasingly difficult to design for higher current ratings. It was a continuing challenge to engineering ingenuity to devise connections which were tidy and would not clash in the wind, but which would allow earthquake movement. The problem of the Bucholz relays was caused primarily by mercury switches which in an earthquake gave a false tripping to the circuit breakers. District staff had devised a pendulum type switch to interrupt the tripping circuit for a short time in the event of an earthquake, and it was being installed on a trial basis.

Permanent repairs to electrical equipment had been hampered by the need to restore accommodation first, and it appeared that houses and buildings for public utilities would better serve their purpose if they were designed to survive such an earthquake, not necessarily without damage, but in working condition. It should be noted that the standard of earthquake resistance provided by the N.Z. Model Building Bylaws NZSS 1900, Chapter 8, was a minimum, and the owner of a building should decide whether for 
economic or operational reasons he would specify and pay for a higher standard of construction. Distribution authorities had much the same problem in locating their lines and services as the department had in locating transmission lines, but they had less choice and were almost always compelled to go along the roads and to meet conditions as they found them, so they had to expect damage in earthquakes. The more modern high voltage equipment in use in other parts of New Zealand had still to be earthquake tested, but it was now known to be more susceptible, and measures were in hand to improve its resistance.

G. K. ARMSTRONG (Dunedin) commented on the damage outlined by Dr Falconer, and said that engineers with some responsibility for public safety could not help but think what damage would result should such an earthquake occur in their own areas. Most cities and towns had a large number of buildings of bearing wall construction, often three or four storeys high, and there were countless unreinforced chimneys, brick veneer dwellings, and so on. In Dunedin in recent weeks the Government, local authorities, and private enterprise had been demolishing some such buildings, in spite of some criticism, but after hearing Dr Falconer he wondered whether the demolition was taking place fast enough.

In addition to responsibility for public safety, engineers had to have due regard for economic considerations. A severe earthquake could occur anywhere in New Zealand, but thought had to be given to the probability of such an occurrence within the useful life of a building. All flood protection works were not designed for the 1,000 year flood, although that would occur some time. In Dunedin there were some three to four storey unreinforced masonry buildings still standing after 70 odd years, without a crack in them. Such hazardous constructions should be replaced in the interests of earthquake safety. He urged engineers also to support their civil defence organisations.

I. D. STEVENSON (Wellington) said that the objectives of engineers, no matter of what persuasion, should be the prevention of injury and death, the protection of property from damage or fire, and the restoration of services as promptly as possible and in a prescribed order of priority in any disaster such as the Inangahua earthquake. To many questions there was no short answer. One such question was whether the power supply should be devised to trip automatically with the onset of an earthquake above a certain magnitude, or whether the discretion should be left to manual operators. More specifically, in one's home should one turn off the power at the onset of an earthquake? Secondly, after power had been disconnected, by no matter what means, should it be restored without investigation, possibly resulting in fire through an overturned radiator or damaged electrical plant? 
Thirdly, what instructions should be promulgated in advance to staff in organisations such as the N.Z.E.D. and power supply authorities, and what instructions should be given by the authorities to consumers of electricity in factories and dwellings? Fourthly, did Mr Hitchcock's investigations of the Inangahua earthquake indicate certain lines of action which should be adopted in the future which had not been in effect at the time? Fifthly, there was the question of standby power for essential services. Since electric power was brought over long distances, it was highly likely it would not be available after an earthquake and that some form of standby power should be planned for in advance. If fixed standby plant were installed - and it would be at considerable cost - there would be the risk that it could be damaged or destroyed by an earthquake, and unserviceable when required. on the other hand, mobile standby plants could be provided at central depots, and taken to devastated areas when required, although there was the risk that road access might be blocked.

It seemed that relatively little damage had been sustained in the earthquake, and that was a tribute to the standards of construction and maintenance observed by the N.Z.E.D. and the power supply authorities in the area.

One matter of paramount importance in any such emergency was the provision of adequate communication services so that those who had to survey the damage and arrange restoration and succour to those in greatest distress could quickly assess the situation and put into effect the necessary organisation. It appeared that mobile radio was the best system, and organisations which would be involved should consider having operative mobile radio in use all the time so that it could be guaranteed to be available in an emergency.

F.P.S. LU (Christchurch) said that earthquake insurance was one way of making more people earthquake conscious, and he drew a comparison with commercially available. fire insurance, in which rates varied according to usage, the nature of construction, and the degree of protection. while a flat rate of 5 cents per $\$ 100$ applied for the government's compulsory scheme of earthquake insurance. He asked if Dr Falconer agreed that the relatively low rate of .05 per cent should be raised substantially - thus replenishing the sadly depleted earthquake fund - or that a variable rate should apply, which would penalise unsafe buildings and encourage safer construction methods.

G. L. EVANS (Christchurch), on the subject of displacement of buildings, commented that one farmhouse had moved 26 inches, and an adjacent highway bridge had moved 8 inches in the same direction. 
Obviously there was difficulty in trying to relate structural movements to ground movements, and the problem of interaction between foundations and structures seemed a very difficult one to solve.

Dr FALCONER said that the Engineering Seismology section of D.S.I.R. had attempted to correlate damage and directions of movement in the Inangahua earthquake, but had found it impossible.

Two points about the governmentally-provided earthquake insurance, for indemnity value, had to be remembered - the cover was compulsory, and the rate was low. If the rate were to be varied according to the risk the costs of collection and inspection would be high and the charge to the insured people would probably be considerably greater. Compulsory earthquake insurance as it currently existed was an extension of commercially-available fire insurance; but, instead of the individual insurer carrying the earthquake risk, the Government Earthquake and War Damage commission carried it, with a special fund (built with the 5 cents per $\$ 100$ premiums) available which was, in effect, under-written by the consolidated Revenue Account. The compulsory cover was limited to buildings, contents, possessions, and various other things - all if insured against fire and not listed in a schedule of exemptions or exceptions in the Earthquake and War Damage Regulations. The Commission had authority to insure other property voluntarily and in such a case it followed the practice of other insurers and assessed the rate according to the risk. He felt the matter was worthy of review at some stage.

Mr HITCHCOCK said the question of whether power supplies should be tripped off automatically was a difficult one. In a severe earthquake there would almost certainly be minor damage such as the clashing of conductors, which would trip the power off. In previous earthquakes the power had been restored progressively, only after inspection of the installations to see if they were safe. The inspection of installations would apply equally in one's own home.

The question of standby power was also a difficult one, and he felt it should be decided in each individual case, balancing the potential loss against the cost of providing a standby. Supply authorities sometimes made special arrangements for special loads, and special circuits might be run so that preference could be given in restoring power.

The use of mobile transmitters after the Inangahua earthquake was evidence of their value in maintaining communications. 